\title{
Technologies and Distance Education with Focus on Teacher
}

\section{Training}

Anair Altoé ${ }^{1}$, Aldevino Ribeiro da Silva ${ }^{1}$, Luciano Gonsalves Costa $^{{ }^{*}}$, Neusa Altoé ${ }^{1} \&$ Heliana da Silva ${ }^{1}$

${ }^{1}$ State University of Maringá, Brazil

*Luciano Gonsalves Costa, E-mail: luciano@dfi.uem.br

Received: July 26, 2016 Accepted: August 8, 2016 Online Published: November 3, 2016

doi:10.22158/wjer.v3n2p502 URL: http://dx.doi.org/10.22158/wjer.v3n2p502

\begin{abstract}
The microelectronics revolution in the twentieth century and the evolution of the profile of Information Technologies and Communication require a teacher able to adapt to a changing world. The simple proposition of using technology in school, with the goal of making teaching innovative, is naive. Teachers need to be trained competently in order to open paths in the construction of their own knowledge and creativity. Therefore, researching the fundamentals of distance education to build a path that allows the university community to access the achievements of this type of education in the initial and continuing training of teachers from the State University of Maringá (UEM) is the challenge before us. For this, we proposed systematic study along with institutional projects to identify activities developed in distance education that make it possible to analyze the proposed teacher education projects developed, identifying actions that enable the initial and continuing training of the teacher within development of the course in the modality of Distance Education (DE).
\end{abstract}

\section{Keywords}

Distance Education, Information Technologies and Communication, Teacher education

\section{Introduction}

In the twentieth century society experienced profound transformations caused by the microelectronic revolution. This revolution created the process of flexible accumulation in the world of work. Information technology and communication required a profile of worker able to adapt to a constantly changing world. These innovations in the computer field generated the need for training and development of human resources and, consequently, studies in the use of the technologies in education. In fact, simply proposing to use technology in schools, with the goal of creating innovative teaching, is a naive proposal. Teachers need to be to be trained to perform competently, to open paths in the construction of their own, creative knowledge (Altoé, 2001). In this sense, Perrenoud (1999, p. 31) has 
claimed that it is necessary to build a set of tools and schemes that permit the mobilization of knowledge in the situation, at the right time and wisely. This implies gaining skills to transpose the pure reproduction of theories and turn them into practical actions that allow the agent access to knowledge as a major factor in education, an organizer of the projects in the search for the construction of new knowledge (UEM, 2012).

Training courses for teachers must seek new paths that lead them to overcome crystallized knowledge and to accept the challenge of surmounting current teacher training, preparing them to face new methodologies of teaching activities both in the classroom environment and in the virtual environment of distance education (Pallof, 2002; Barbosa, 2005; Sancho, 2006).

Education in this context takes on an ambitious role for the development of individuals and society. The pursuit of knowledge has become a constant nowadays, because opportunities for learning should always be valued and enjoyed for a lifetime. This means that a lot is expected of teachers, they should prepare their students so that, not only will they be able to face the future with confidence, but they will also be able to build it themselves in a determined and responsible manner (UEM, 2011). We believe that Brazil, with its geographical dimension and the large number of people who seek higher education, may find in the mode of Distance Learning (DL) an important solution for the qualification of those who seek training in a higher education course. When we look closely at the development of Distance Education Courses (DEC) we can see that every day more Brazilians enroll in courses, especially in higher education. Data from the 2010 Higher Education Census show that DL did not exist a decade ago and now accounts for $14.6 \%$ percent of total undergraduate enrollment. In 2001, only 5,359 students were enrolled in the modality of distance learning courses. A decade later, this number has increased 170 times, reaching 930,179 students attending this mode of education. The EAD.BR Census-Analytical Report on Distance Learning in Brazil 2012, organized by the Brazilian Association for Distance Education (ABED), presents new results (EAD BR Census, 2012).

The Open University of Brazil (UAB) system, when established in 2006, officially established the offering of distance education courses through public higher education institutions. The document that instituted this system was Decree n. 5,800 of 8 June, 2006 (Educational Studies and Research, 2012), signed by President Luiz Inacio Lula da Silva and the Minister of Education, Fernando Haddad. It is worth highlighting the first article of this decree:

Art. 1. The Open University System in Brazil-UAB - is established, geared to the development of the modality of distance education, in order to expand and internalize the provision of courses and higher education programs in the country (Brazil, 2006).

However the guidelines of the courses, especially those of Pedagogy were not changed and thus retained the same principles and fundamentals as in classroom teaching. In this regard it is worth pointing out that $[\ldots]$ The guidelines established involve content, methodology, practice and research, making the training of the teacher complex in the face of the actual conditions of the institutions. It becomes even more complex when Information and Communication Technologies (ICTs) are used as 
instruments of mediation in teaching and learning processes (Educational Studies, 2012, p. 293).

It is not enough just to enable Distance Education courses based on traditional approaches to teaching permeated by digital technology resources. Pedagogical issues contribute little or nothing to the development of skills and competencies focused on autonomy, creativity, and learning to learn, among others. It is misleading to expect an educational activity that favors the transmission of information to present a product that results in the construction of knowledge (Valente, 2003).

Teachers play an important role in shaping attitudes-positive or negative-with regard to study. They can stimulate curiosity, develop autonomy, enhance intellectual rigor and create the necessary conditions for formal and continuing education, and thus the importance of the role of the teacher as agent of change needs to be appreciated (Fregoneis et al., 2011).

In particular, at the State University of Maringá (UEM) initiatives emerged for the implementation of courses in data processing and computing in 1975. Therefore, to see how the process of deploying IT applications in education occurred, information was sought from the "pioneers of computing at UEM", currently retired teachers, who contributed to the research, describing their experiences during the implementation of courses within the institution. In addition, projects developed at UEM were examined to understand the trajectory of this institution in the implementation and development of information technology applied to education.

\section{Method and Discussion}

When researching the fundamentals of computer technology applied to education and other media, we sought to construct the trajectory that would allow the university community access to the achievements of technology in initial and continuing teacher education (Valente, 1993; Moraes, 1997; Masetto et al., 2000; Altoé, 2001).

Consequently, a register was established consisting of projects related to teaching, research and extension which demonstrated actions developed in pedagogical activities which showed the possibilities of using computer technology in education both within the university community and more broadly, in the general community. The reading, observation and direct and intensive reflection on the projects registered was the means by which the research data was obtained (UEM, 2012).

It was discovered that the first electronic correction of the unified entrance exam took place in 1972. Thus, since 1970 there have been studies on the use of computers in the institution (UEM, 2012). Projects developed at UEM aimed to prepare human and technical resources for training others in the use of the technologies, especially where applied to education, from the time that UEM began its journey in the deployment of innovative courses.

The literature review sought to explain and answer the problems analyzed in a theoretical dimension constituting a formal procedure for the acquisition of new knowledge. It required the development of reflective thinking and scientific treatment in the in-depth search for answers to the questions involved in the research. Further analysis of the data collected enabled the articulation between theory and 
practice in the construction of proposed pedagogical projects for the activity of the teacher in initial training, in the computerized environment, especially with the use of Information and Communication Technologies in Education (UEM, 2012).

Theoretical studies enabled an analysis of teacher training in accordance with the proposal developed by the projects consulted. The proposal for actions that enable initial and continued training of the teacher in the use of information and communication technologies was one of the questions that could be addressed subsequent to completing this research.

The effective contribution of a proposal for intervention in the initial and continued training of teachers on various degree courses at UEM, in the use of the computer as an educational tool in the classroom, occurred as a result of the better overview the researchers gained from the more than two hundred projects consulted. These projects were distributed in the three areas of expertise of the university, namely: teaching, research and extension.

It was found that the dynamic approach to research activities through selected content encompassed the aim to qualify teachers and students on undergraduate courses to explore, technically and pedagogically, Information and Communication Technologies in the teaching and learning environment.

Another important aspect was the establishment and implementation of the study group for analysis of the proposal for the use of computers in educational environments, especially Information and Communication Technologies in the educational area at various levels of teaching, research and extension.

\section{Results}

The analysis undertaken in the projects registered and developed in and by UEM indicated aspects that deserve attention (UEM, 2012). They are:

a) recognition of information technology as a precursor in an incipient period, with few resources and difficulty of access, especially in the implementation phase: 1970-1980;

b) the efforts of the teachers and staff of UEM who even decamped to other centers of knowledge production, for personal advanced training and subsequent dissemination of the knowledge acquired upon return to academic activities, starting in 1990 and, with greater emphasis, since 2000;

c) the courses taken, the orientation activities and the development of specific projects for the area, and the resulting qualification of teachers and students of the university derived from the acquisition, from the development and the dissemination of knowledge and skills gestated in the elaboration of courses, from 1970 to the present day;

d) UEM oversaw and participated in the advances, development and implementation of the use of Information and Communication Technology, in education, in the various fields and at the various times in which they were developed;

e) the wealth provided by Information and Communication Technology in various fields of study, teaching, research and extension reaffirms the essential permanent requirement to maintain this area up 
to date, since it presents continuous and rapid discoveries, advances and developments at various levels of education, research and extension practiced in regional, national and international higher education institutions;

f) the need to redesign the procedures for initial teacher training for the various levels of education, and in particular, for the activity of Distance Education, which constitutes a wide field of research.

\section{References}

Altoé, A. (2001). A gênese da informática na educação em um curso de pedagogia: Ação e mudança da prática pedagógica. 303f. Tese (Doutorado-Programa de Pós-Graduação em Supervisão e Currículo)-Pontifícia Universidade Católica de São Paulo, São Paulo.

Barbosa, R. M. (2005). Ambientes virtuais de aprendizagem. Porto Alegre: Artmed.

BRASIL. (2006). Presidencia da República. Casa Civil. Decreto $n^{\circ} 5.800$, de 8 de junho de 2006.

Retrieved January

9 , 2014 ,

from

http://www.planalto.gov.br/ccivil_03/_ato2004-2006/2006/decreto/d5800.htm

Censo EAD. BR. (2013). Relatório analítico da aprendizagem a distância no brasil $2012=$ Censo EAD. BR: Analytic Report of Distance Learning in Brazil/[traduzido por Opportunity Translations]. Curitiba: Ibpex. Retrieved December 5, 2013, from http://www.abed.org.br/censoead/censoEAD.BR_2012_pt.pdf

ESTUDOS e PESQUISAS EDUCACIONAIS. (2012). nov 2012-Fundação Victor Civita, São Paulo.

Fregoneis, J. G., Altoé, A., Costa, L. G., \& Silva, A. R. (2011). Uso da tecnologia computacional na educação: Competências e atitudes de professores. Revista Científica Inovação e Tecnologia. Universidade Tecnológica do Paraná. Campus de Medianeira, 1(3), 11-17.

MASETTO. (2000). Marcos T. Mediação pedagógica e o uso da tecnologia. In J. M. Moran, M. T. e Masetto, \& M. A. Behrens (Eds.), Novas tecnologias e mediação pedagógica (pp. 133-173). Campinas.

Pallof, R. M. (2002). Construindo comunidades de aprendizagem no ciberespaço. Porto Alegre: Artmed.

Papirus, M, M. C. (1997). O paradigma educacional emergente. Campinas: Papirus [Coleção Práxis].

Perrenoud, P. (1999). Construir as competências desde a escola. Trad. Bruno Charles Magne. Porto Alegre: Artes Médicas.

Sancho, J. M. (2006). Tecnologias para transformar a educação. Porto Alegre: Artmed.

Valente, J. A. (1993). Computadores e conhecimento: Repensando a educação. Campinas: Gráfica Central da UNICAMP.

Valente, J. A. (2003). Educação a distância no ensino superior: Soluções e flexibilizações. Revista $\begin{array}{llll}\text { Interface-Comunic. } & \text { Saúde, } & \text { Educ, } & 7(12),\end{array}$ http://dx.doi.org/10.1590/S1414-32832003000100010 